\title{
Changes in Rainfall Characteristics in Wenchi and Saltpond Farming Areas of Ghana
}

\section{Kwesi Akumenyi Quagraine ${ }^{1 *}$, Nana Ama Browne Klutse ${ }^{1,2}$, Francis Nkrumah1, David Cudjoe Adukpo', Kwadwo Owusu ${ }^{3}$}

\author{
${ }^{1}$ Department of Physics, University of Cape Coast, Cape Coast, Ghana \\ ${ }^{2}$ Ghana Space Science and Technology Institute, Ghana Atomic Energy Commission, Accra, Ghana \\ ${ }^{3}$ Geography Department, University of Ghana, Accra, Ghana \\ Email: *kwesi.quagraine@ucc.edu.gh
}

How to cite this paper: Quagraine, K.A. Klutse, N.A.B., Nkrumah, F., Adukpo, D.C. and Owusu, K. (2017) Changes in Rainfall Characteristics in Wenchi and Saltpond Farming Areas of Ghana. International Journal of Geosciences, 8, 305-317. https://doi.org/10.4236/ijg.2017.83015

Received: November 15, 2016

Accepted: March 24, 2017

Published: March 28, 2017

Copyright $\odot 2017$ by authors and Scientific Research Publishing Inc. This work is licensed under the Creative Commons Attribution International License (CC BY 4.0).

http://creativecommons.org/licenses/by/4.0/

\begin{abstract}
Ghana's economy heavily relies on agriculture, which is predominantly rainfed across its agro-ecological zones. As a result of this, it is vulnerable to rainfall variability, which tends to have a major impact on the industrial and agricultural production sectors of the country. This study investigates the variations occurring across two major farming areas (Wenchi and Saltpond) within the Transition and Coastal Savannah agro-ecological zones of Ghana respectively. Rainfall variations are studied with rainfall data from 1968-2011 from Ghana Meteorological Agency (GMet). The rainfall analysis is done over two Climatological Periods (CP), 1968-1989 as CP1 and 1990-2011 as CP2. This study uses two climatic extreme indices as well as rainfall amounts and onset over these two agro-ecological zones to investigate the changes that have occurred in rainfall. The study found that in the Coastal agro-ecological zone, $\mathrm{CP} 1$ had a decreasing rainfall trend as compared to CP2 with higher variations in Saltpond. In the Transition agro-ecological zone, Wenchi, CP1 also exhibited a decreasing trend as compared to CP2. In addition, onset of rains in Saltpond mostly occurred in May for CP1 but for CP2, it oscillated between April and May. For Wenchi, onset of rains was in March for CP1 and predominantly April for CP2. In going forward, farmers in these agro-ecological zones should be supported to practice effective adaptation and mitigation measures so as to improve their yields in this challenging climate.
\end{abstract}

\section{Keywords}

Climate Variability, Rainfall, Extreme, Onset, Agro-Ecological Zones, Ghana

\section{Introduction}

Rainfall has major influence on industrial and agricultural production in any 
agro-ecological zone in the world. Changes in the amount and pattern of rainfall over Ghana are therefore, a major concern. These changes may affect the onset and length of rainfall, which has implication for Ghana's rain-fed agriculture. Ghana's economy relies greatly on agriculture and it accounts for the rise in the Gross Domestic Product (GDP) of the country in most years. This sector also employs almost half of the economically active population [1].

Countries in Africa, especially those in West Africa are most prone to the impact of climate change [2]. This is because of their substantial dependence on rain-fed agriculture and their poverty that leaves them vulnerable to climate stress. Findings from the Fifth Assessment Report of the IPCC indicates that although the West African monsoon winds are likely to weaken, there will very likely be intensification of monsoon precipitation as a result of increase in atmospheric moisture. However, the report stresses that monsoon retreat dates will be delayed thereby increasing the length of the monsoon season. West Africa is very likely to see a $2.8 \%$ increment in rainfall as reported in IPCC's AR5 [3].

The study reported that extreme events would very likely intensify and much more frequent. These increments may yield to an increase in extreme events, which may be destructive to both human and natural systems. However, it can be realized that whereas some places will experience an increase in their annual rainfall, others may experience a decrease, which may even lead to drought. Nicholson [4] mentioned a 10\% increase in annual rainfall along the Guinean coast during the last 30 years has been observed. In West Africa, a decline in annual rainfall has been observed since the end of the 1960s with a decrease of 20 to $40 \%$ noted from 1968 to 1990 [5], particularly in the tropical rain-forest zone, declines in mean annual precipitation of around $4 \%$ in West Africa, 3\% in North Congo and 2\% in South Congo for the period 1960 to 1998 have been noted [6]. In Ghana, decreasing trends in rainfall amounts have been reported [7] [8].

The impacts of climate change is manifesting through changes in extreme events such as droughts and floods. Such extremes can be detrimental to human life, and hamper economic development. Unfortunately, assessments of future climate change are often limited to mean temperature and precipitation. Less attention has been given to future changes in extremes particularly for Africa until recently, e.g. over southern Africa [9] [10] [11] and West Africa [12]. Information of the past extreme climate events in Ghana will provide a guide for future trends for possible consideration in planning and decision-making.

The variations observed in the amount and pattern of rainfall make it challenging for easy prediction, however a prior knowledge of the variations will help the farmer plan for possible maximization of crop yield. Information on the changes in onset or the trend of rainfall over a particular period is used to make decisions and policies on rainfall dependent sectors. The start of rains marks the start of the main farming season in Ghana. The rainfall season is usually considered to be the planting period for some of the main staple crops, such as maize, beans and potatoes in Ghana [13]. Therefore it is imperative that rainfall variability is well studied in these areas so that farmers can be enlightened to help 
control loss of yield.

The paper aims to study the changes in the mean rainfall, extremes and onset dates within the transition and coastal savannah zones of Ghana for two climatic periods, 1968-1989 and 1990-2011. In the paper, analysis of rainfall intensity, consecutive wet days, consecutive dry days and onset dates over the two climatological periods are presented and discussed. This paper will inform farmers on the pattern and changes that are occurring in rainfall onset and amount in the Transition and Coastal Savannah agro-ecological zones of Ghana. It will also inform appropriate interventions for farming in the two agro-ecological zones to reduce the impact of the changes in the climate.

\section{Study Area}

Ghana's climate is classified as tropical and is characterized generally by two rainfall seasons. Saltpond is in the Coastal Savannah Zone, which is called Zone A according to the classification of Ghana Meteorological Agency (GMet). The zone experiences two rainfall seasons, the major season occurs between March and July and the minor season occurs around September to November. The annual total rainfall is about 700 to $800 \mathrm{~mm}$. The vegetation along the coast is the coastal savannah with grassland and few trees.

Wenchi is in the Transition Zone, which is identified as Zone $\mathrm{C}$ according to the GMet. The zone experiences two rainy seasons: a minor (April to July) and a major (September to November). There is not much distinction between the amounts of rainfall in the two rainy seasons and so they appear as one continuous season [14]. This zone normally records a mean annual rainfall of about $1200 \mathrm{~mm}-1800 \mathrm{~mm}$.

Figure 1 shows the agro-ecological zones according to the classification of GMet with the Transition and Coastal Savanna zones positioned in Zone C and Zone A respectively. The two agro-ecological zones 1) are in different stages of economic development but 2) have agriculture that is largely dependent on rainfall. The choice of these two stations in the two agro-ecological zones was informed by the study areas of the PEER science project carried out at the Department of Physics, University of Cape Coast, Ghana under the kind sponsorship of the USAID. This study is a part of the PEER science project.

\section{Data and Methods}

The station data used in this analysis were obtained from the Ghana Meteorological Agency. The data used for this analysis represent two synoptic stations (Wenchi and Saltpond), which represent the Transition and Coastal Savannah zones of Ghana. It should be noted that other stations close-by to these two synoptic stations exhibited similar trends and as such one in each of the two agro-ecological zones was chosen for the analysis. The climatological variable used was daily rainfall data spanning from 1968 to 2011. The data for the selected stations were quality controlled using RClimdex which uses the R statistical package. Periods without data for all the climatological variables were set to 


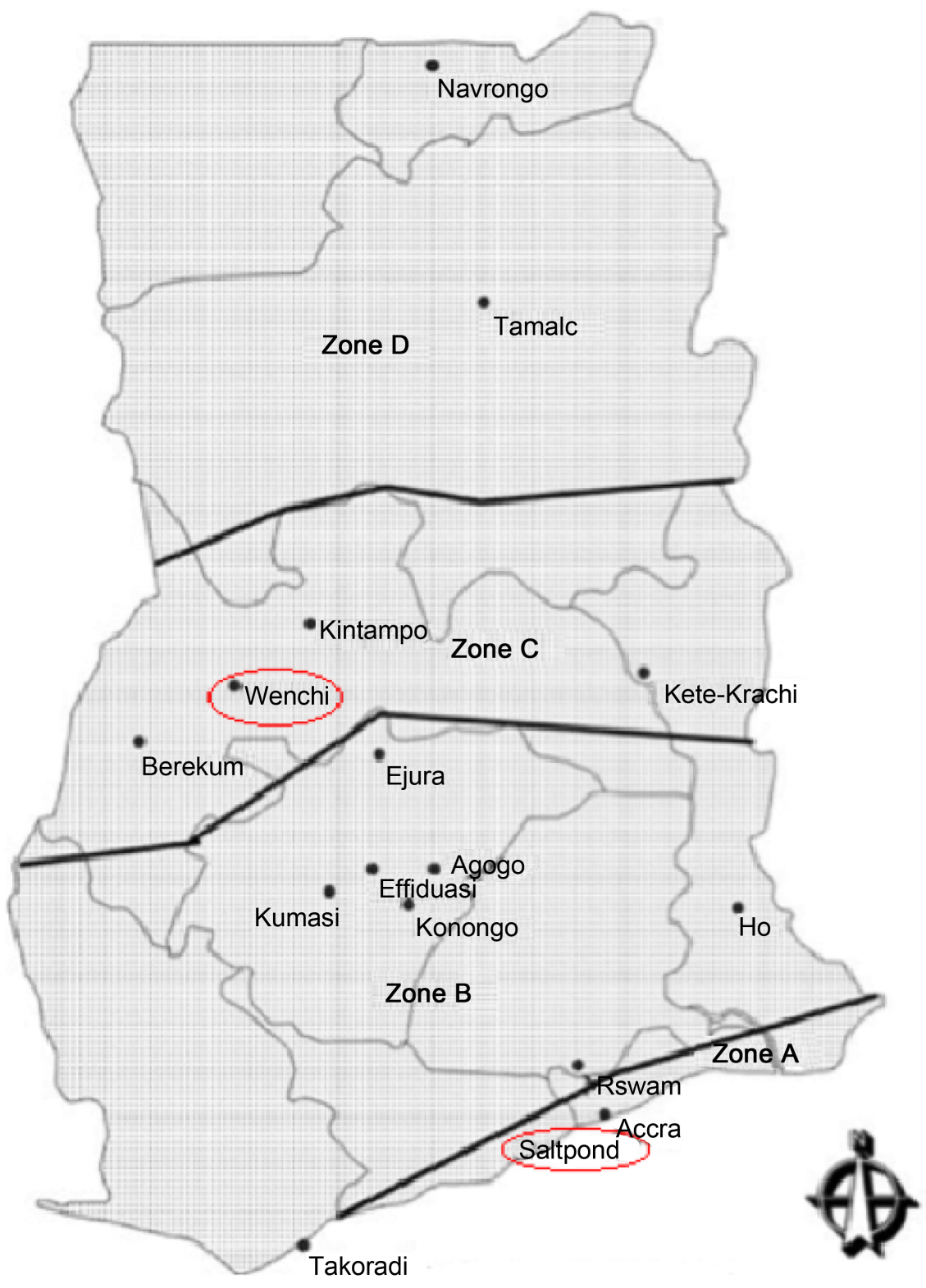

Figure 1. Agro-ecological zones of Ghana with selected cities, Wenchi and Saltpond.

a missing value of -99.9. With this threshold setting, RClimdex identifies values that lie outside 4 standard deviations of the mean of the time-series. The quality control on the data was conducted to eliminate errors in the data. Errors emanating from manual keying and negative daily precipitation amount were corrected after cross checking from the original hard copy.

The data was analyzed over two climatic periods, 1968-1989 and 1990-2011, hereafter called CP1 and CP2 respectively. The climatological periods were chosen in order to have a past and current comparison of the available data to discuss the trend of rainfall over the past years. The periods chosen have the years with most complete data with less than $10 \%$ missing data. The intensity of rainfall and rainfall onset for each station was determined for CP1 and CP2 using the InStat-plus version 3.05 programming tool from GraphPad Software, San Diego 


\section{California, USA.}

The Consecutive Dry Days (CDDs) and Consecutive Wet Days (CWDs) were computed to study the daily characteristics of extreme events over the chosen climatological periods. CDD is defined as the count of number of consecutive days where daily rainfall amount is less than $1 \mathrm{~mm}$. CWD is defined as the count of number of days where daily rainfall amount is equal to or more than $1 \mathrm{~mm}$. These rainfall characteristics will suggest possibilities of increased floods or drought spells occurrences for the CP1 and CP2.

Rainfall onsets in both the Transition (Wenchi) and Coastal Savannah (Saltpond) over CP1 and CP2 were determined using InStat-plus to study the differences that has occurred in recent years relative to the past. The definition for rainfall onset is borrowed from Raman (1974) who defined onset as the first occasion of 7-day total rainfall exceeding $25 \mathrm{~mm}$ and includes at least 4 rainy days.

\section{Results and Discussion}

Figure 2 shows the annual rainfall totals for CP1 and CP2 over Saltpond. The figure shows that CP1 exhibits high variation with a reduced amount of rainfall in most years over the period compared to CP2 as there were more lows than highs in CP1 than CP2. A decreasing trend line demonstrates the extent of the decrease in the annual rainfall in CP1. This decreasing trend in rainfall has also been reported [7] [8] over Ghana and particularly over the southern part [15] [16].

Over the CP2 period, Saltpond recorded an overall increasing trend with high variation in the 1990s than in the 2000s (Figure 2). This statistically shows that there has been some steadiness in rainfall pattern over the 2000s in Saltpond. The increasing trend of CP2 annual rainfall disagrees with the trend [7] [8] for rainfall in Ghana. Most especially, the 2000s recorded a consistent increase in the amount of annual rainfall between $714 \mathrm{~mm}$ and $1274 \mathrm{~mm}$ with more years recording above $900 \mathrm{~mm}$.

Annual rainfall amount over Wenchi for CP1 (Figure 3) shows a slightly

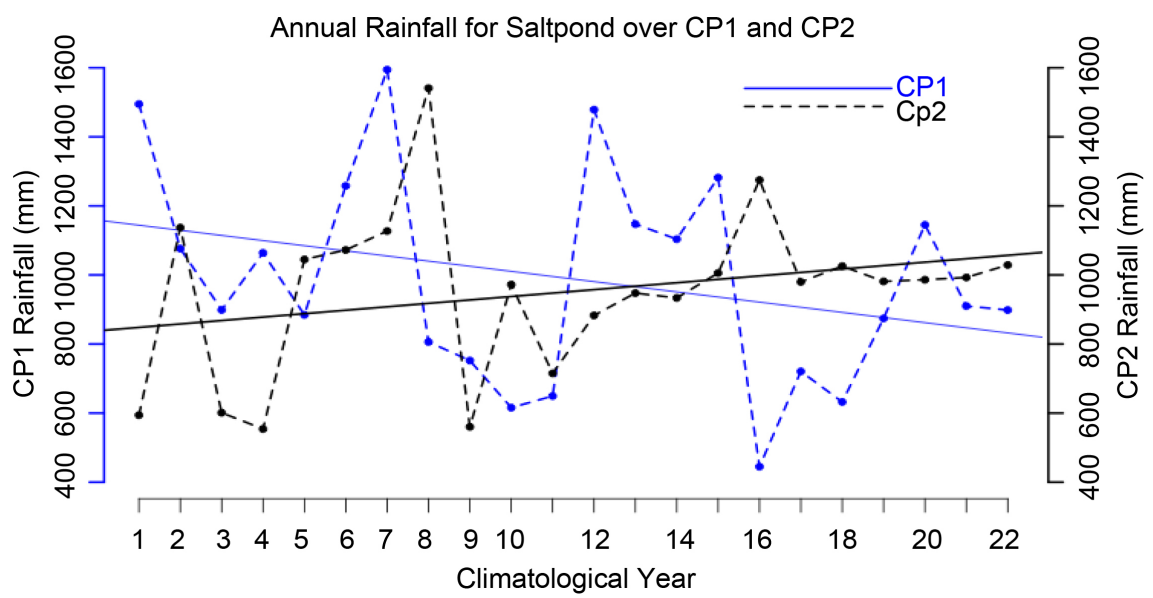

Figure 2. Annual rainfall amounts over Saltpond CP1 for CP2 with estimated regression lines respectively. 


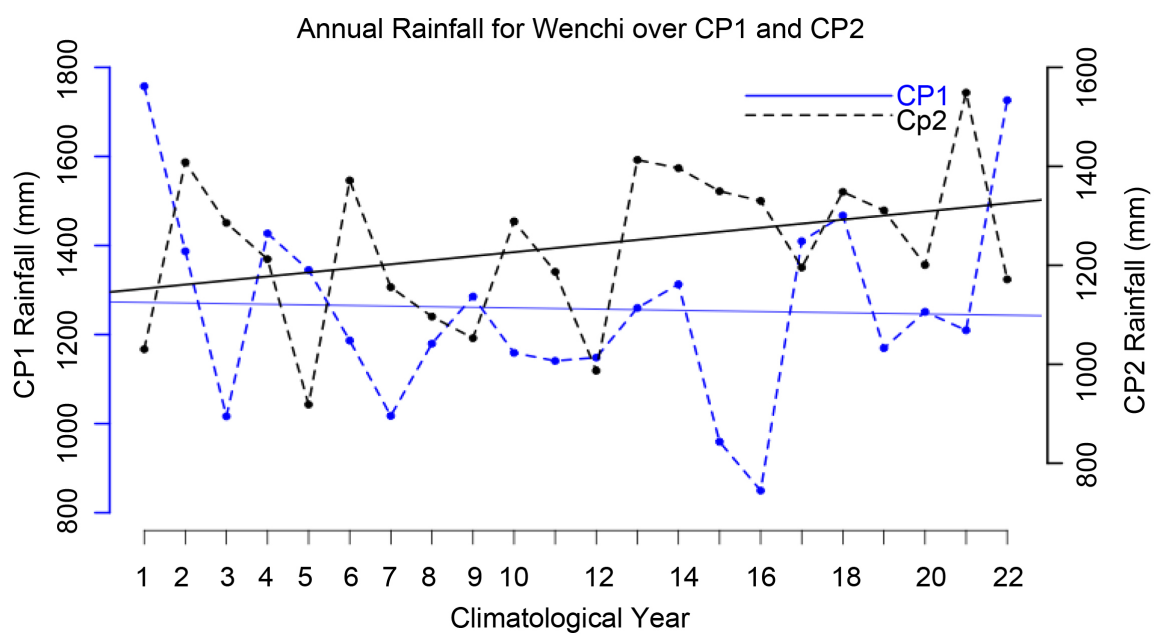

Figure 3. Annual rainfall amounts over Wenchi for CP1 and CP2 with estimated regression lines respectively.

decreasing trend from 1968 to 1989. Rainfall amount ranged from $1387 \mathrm{~mm}$ to about $1427 \mathrm{~mm}$ in the $1960 \mathrm{~s}$ and range from $849 \mathrm{~mm}$ to $1726 \mathrm{~mm}$ in the $1970 \mathrm{~s}$ and 1980s with most years recording $1150 \mathrm{~mm}$. Annual variations in the $1960 \mathrm{~s}$ and 1980s are higher than in the 1970s. Similarly for Wenchi in the CP2 period (Figure 3), the amount of rainfall was found to be decreasing in the recent years especially in the 2000s but showed an overall increasing trend.

Consecutive Dry Days (CDD) shows an increasing trend over Saltpond (Figure 4) with high variations over the years in the CP1 period. A p value of $0.046<0.05$ implies a significant increasing trends in CDD during the CP1 period over Saltpond. For CP2 period, a non-significant evidence of decreasing CDD exists over Saltpond (Figure 5) with a p value of $0.171>0.05$.

Similarly over Wenchi, there is a significant evidence of increasing CDD (Figure 6) as suggested from the $\mathrm{p}$ value $0.008<<0.05$ but the CP2 period shows a non-significant decrease in trend of the CDD (Figure 7) with a $\mathrm{p}$ value of $0.405>>0.05$.

For Consecutive Wet Days (CWD), a consistent decreasing trend is observed over both Saltpond and Wenchi during the two climatological periods (Figures 8-11). However during the CP1 (CP2) for both study areas, a non-significant decrease was observed with a $\mathrm{p}$ value of $0.18 \gg>0.05(0.576>>0.05)$ and $0.112>0.05(0.643>>>0.05)$ for Saltpond and Wenchi respectively. This agrees as inversely proportional to the increasing trend of CDD and depicts the possibility of increasing droughts, which will be detrimental to farming practices.

Table 1 presents the onset dates of rainfall in CP1 and CP2 over Saltpond and Wenchi while in Figure 12 and Figure 13 the plots show their variability in the onset dates. This enables us to know the changes that have occurred in the onset and amount of rainfall. These changes are important for farmers and decision makers.

For Saltpond, rainfall onset mostly occurred in May for CP1 but oscillated closely between April and May in CP2. For Wenchi, the table shows that the 


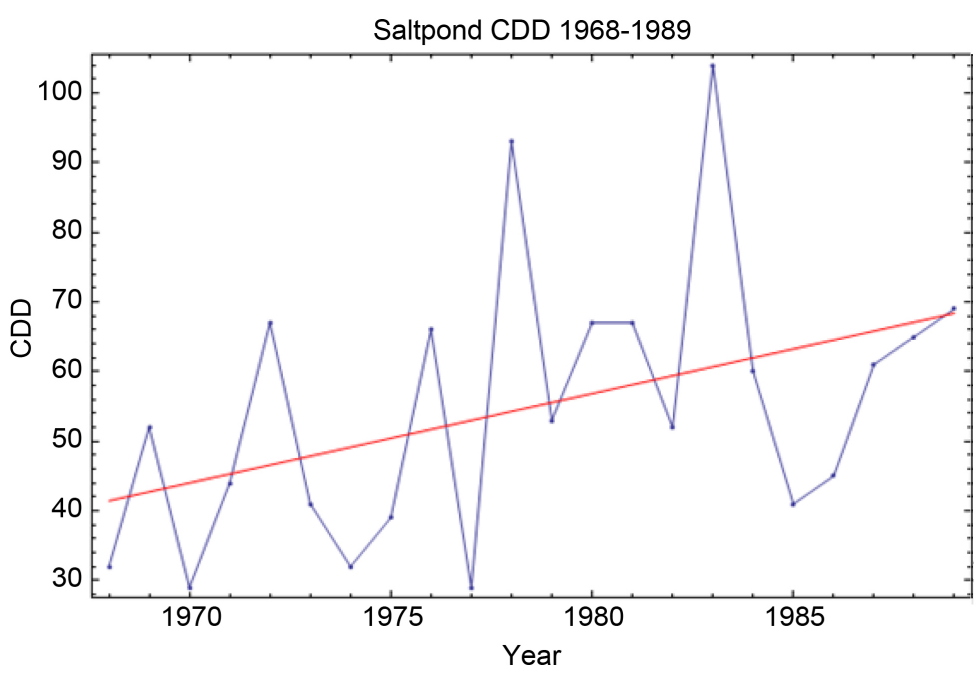

Figure 4. Consecutive Dry Days (CDD) over Saltpond for CP1.

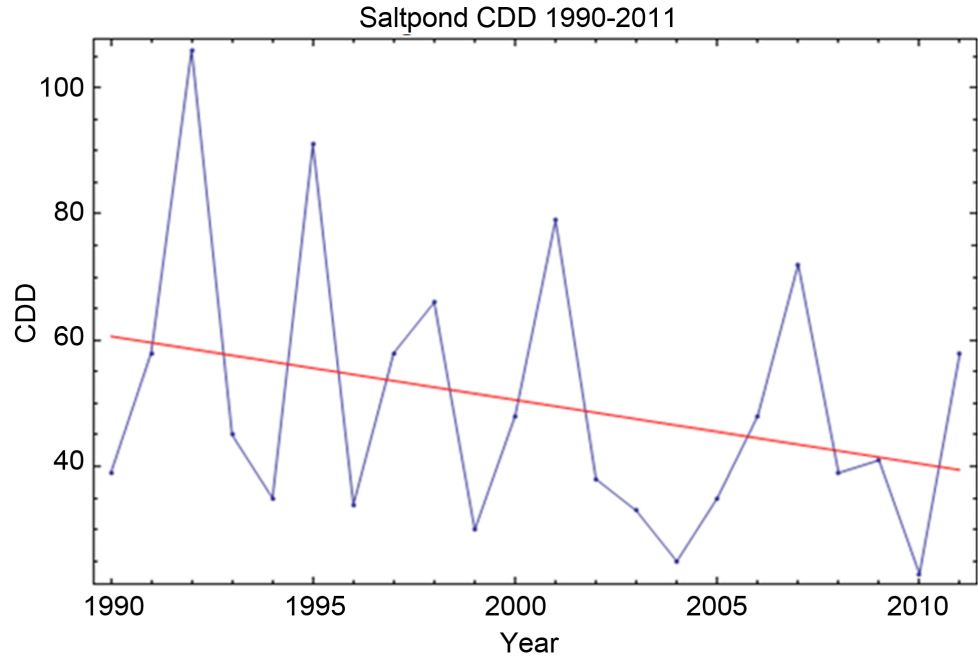

Figure 5. Consecutive Dry Day (CDD) over Saltpond for CP2.

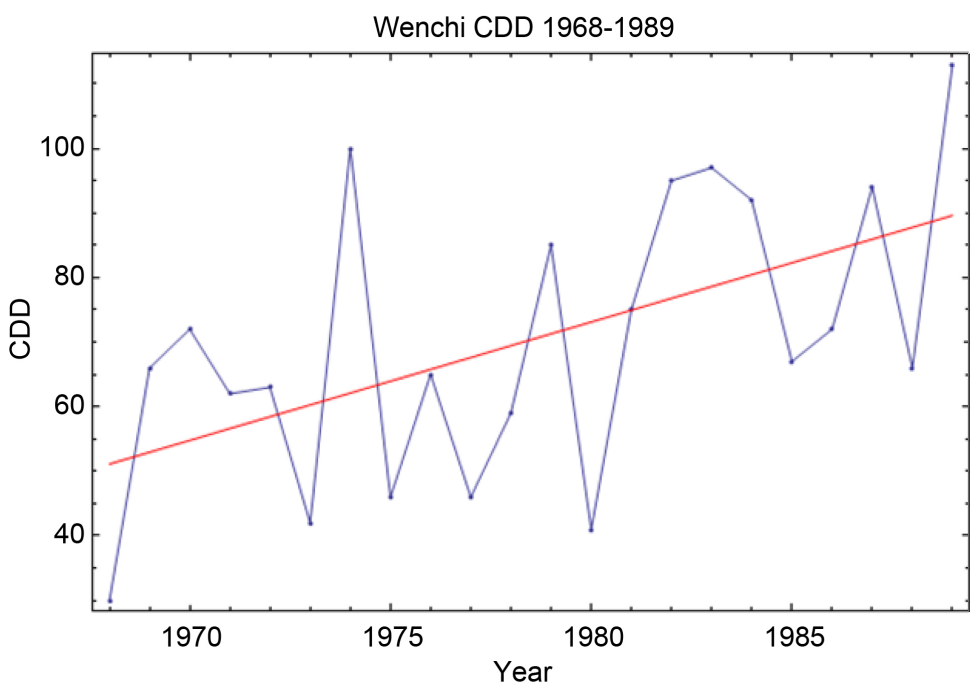

Figure 6. Consecutive Dry Days (CDD) over Wenchi for CP1. 


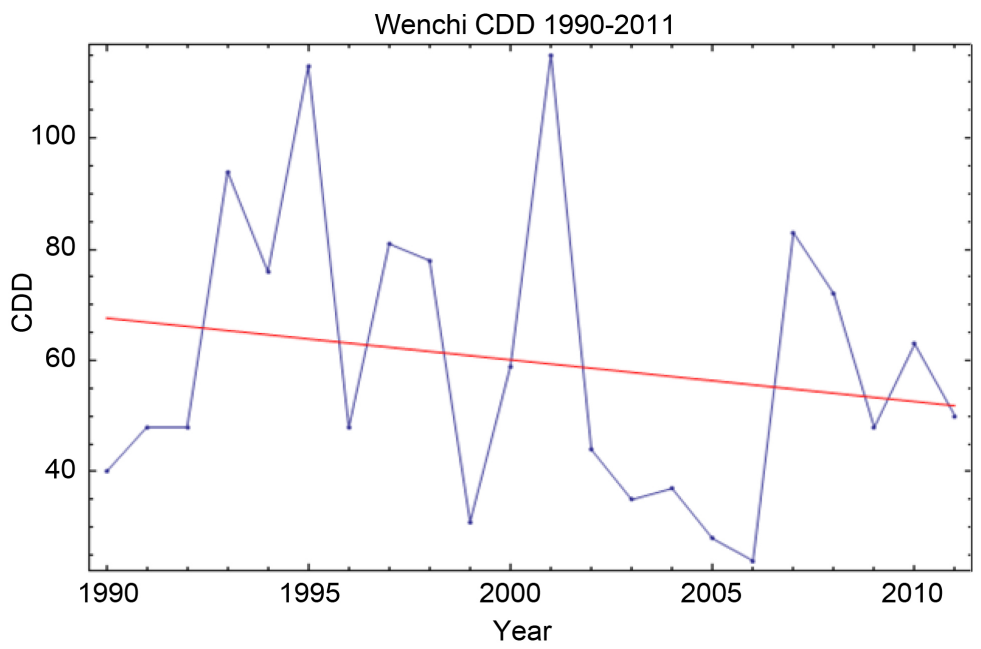

Figure 7. Consecutive Dry Days (CDD) over Wenchi for CP2.

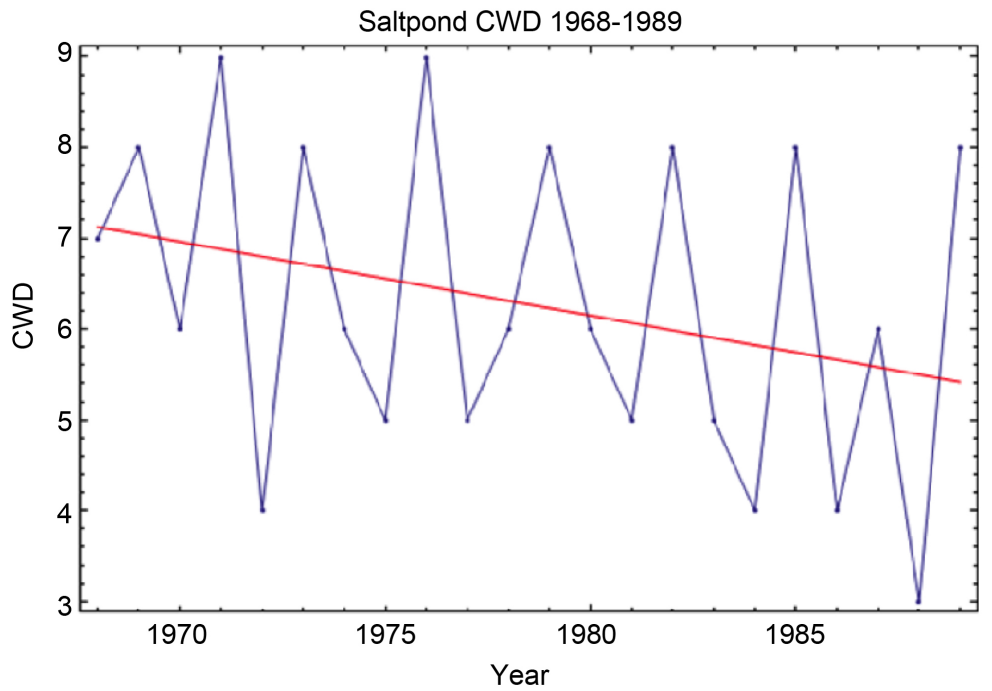

Figure 8. Consecutive Wet Days (CWD) over Saltpond for CP1.

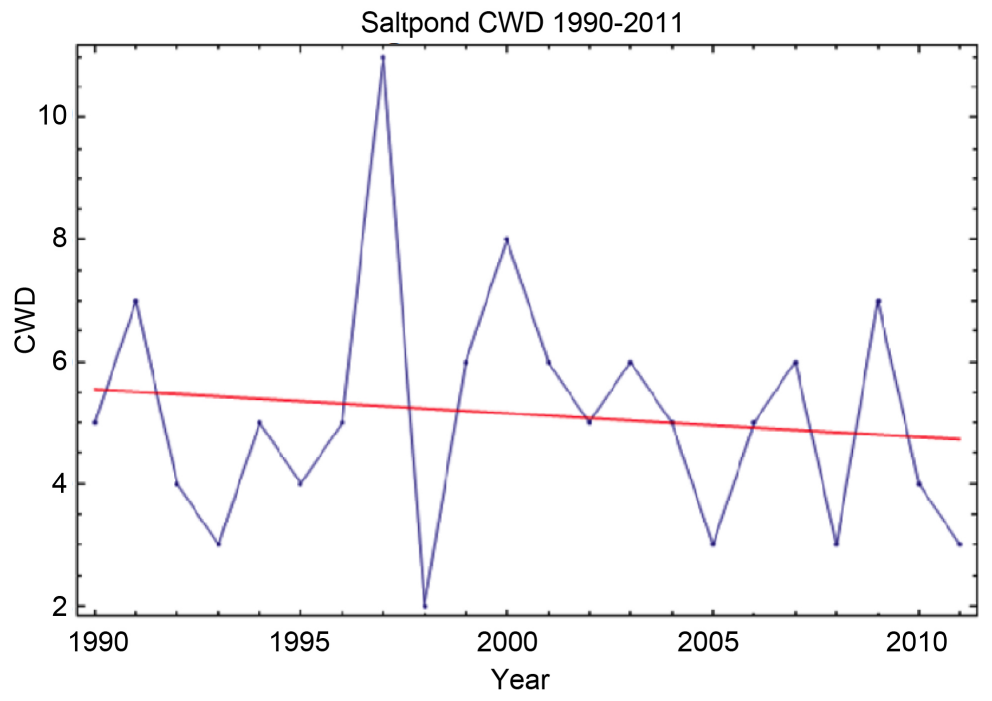

Figure 9. Consecutive Wet Days (CWD) over Saltpond for CP2. 


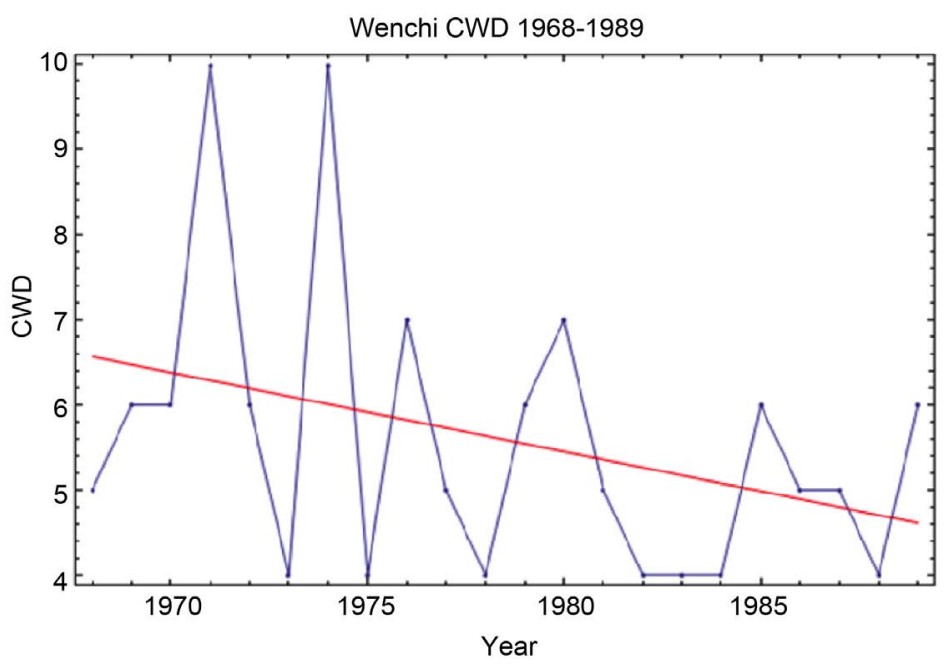

Figure 10. Consecutive Wet Days (CWD) over Wenchi for CP1.

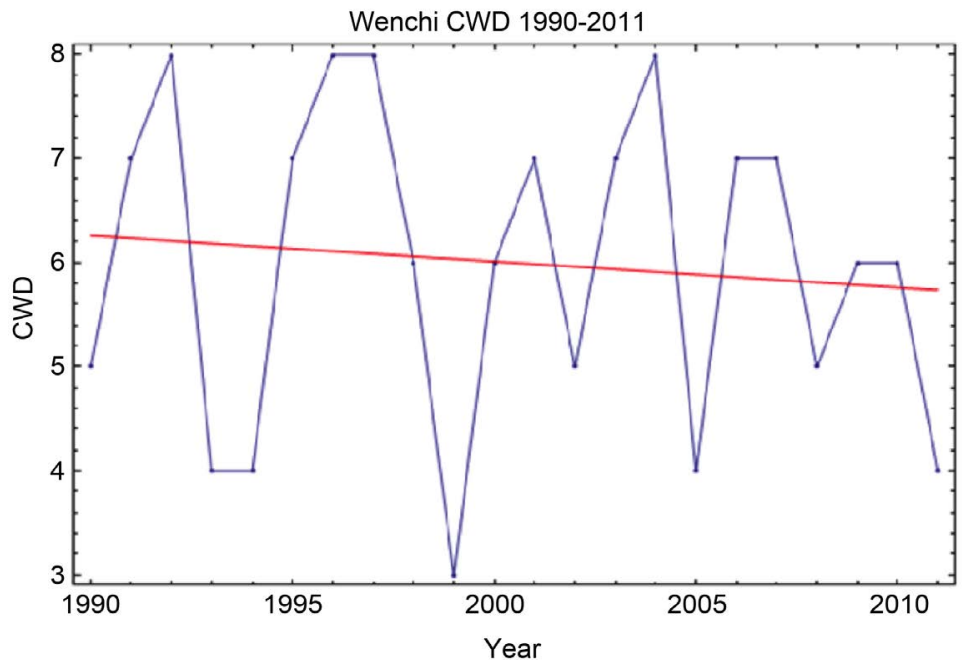

Figure 11. Consecutive Wet Days (CWD) over Wenchi for CP2.

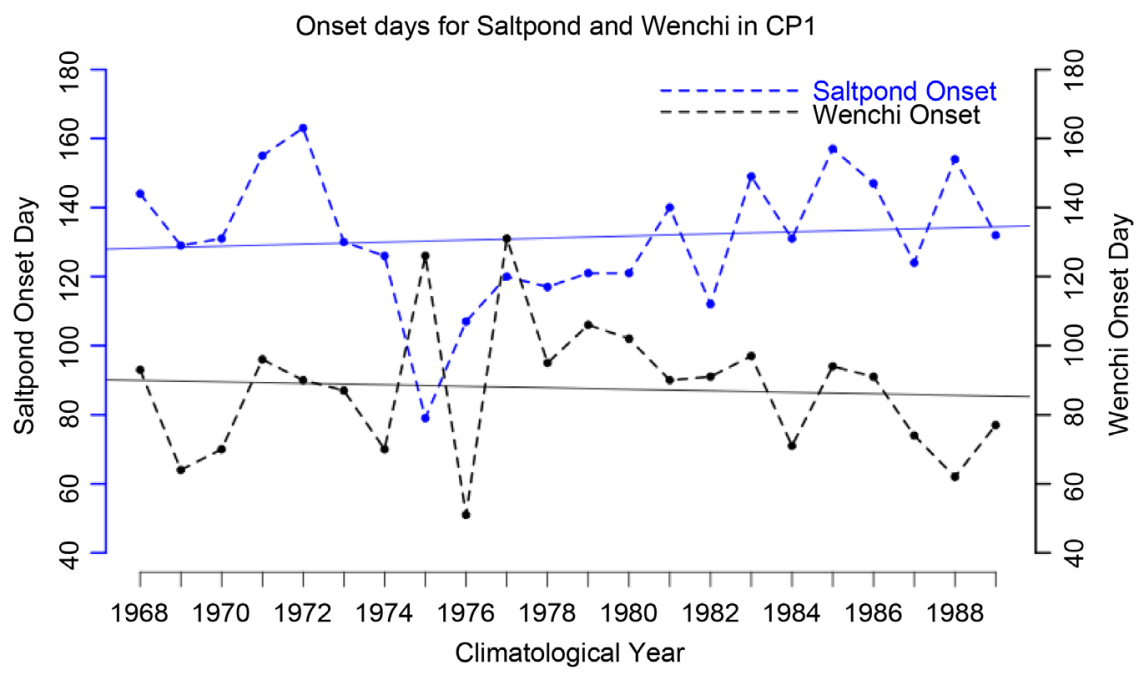

Figure 12. Onset days for Saltpond and Wenchi in CP1 with estimated regression lines respectively. 


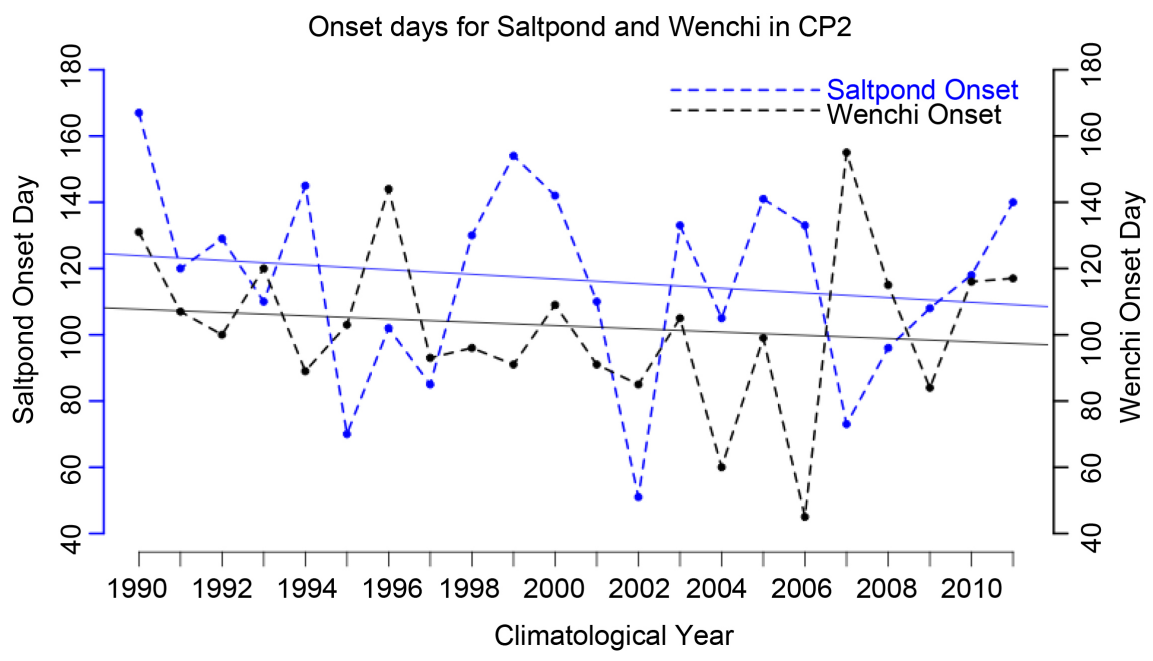

Figure 13. Onset days for Saltpond and Wenchi CP2 with estimated regression lines respectively.

Table 1. Onset dates for Saltpond and Wenchi in CP1 and CP2.

\begin{tabular}{|c|c|c|c|c|c|}
\hline \multicolumn{3}{|c|}{$\mathrm{CP} 1$ Onset dates } & \multicolumn{3}{|c|}{ CP2 Onset dates } \\
\hline Years & Saltpond & Wenchi & Years & Saltpond & Wenchi \\
\hline 1968 & 23-May & 2-Apr & 1990 & 16-Jun & 11-May \\
\hline 1969 & 9-May & 5-Mar & 1991 & 30-Apr & 17-Apr \\
\hline 1970 & 11-May & 11-Mar & 1992 & 8-May & 9-Apr \\
\hline 1971 & 4-Jun & 6-Apr & 1993 & 20-Apr & 30-Apr \\
\hline 1972 & 11-Jun & 30-Mar & 1994 & 25-May & 30-Mar \\
\hline 1973 & 10-May & 28-Mar & 1995 & 11-Mar & 13-Apr \\
\hline 1974 & 6-May & 11-Mar & 1996 & 11-Apr & 23-May \\
\hline 1975 & 20-Mar & 6-May & 1997 & 26-Mar & 3-Apr \\
\hline 1976 & 16-Apr & $20-\mathrm{Feb}$ & 1998 & 10-May & 6-Apr \\
\hline 1977 & 30-Apr & 11-May & 1999 & 3-Jun & 1-Apr \\
\hline 1978 & 27-Apr & 5-Apr & 2000 & 21-May & 18-Apr \\
\hline 1979 & 30-Apr & 16-Apr & 2001 & 20-Apr & 1-Apr \\
\hline 1980 & 30-Apr & 11-Apr & 2002 & $20-\mathrm{Feb}$ & 26-Mar \\
\hline 1981 & 20-May & 31-Mar & 2003 & 13-May & 15-Apr \\
\hline 1982 & 22-Apr & 1-Apr & 2004 & 14-Apr & $1-\mathrm{Feb}$ \\
\hline 1983 & 29-May & 7-Apr & 2005 & 21-May & 9-Apr \\
\hline 1984 & 10-May & 11-Mar & 2006 & 13-May & 14-Feb \\
\hline 1985 & 6-Jun & 4-Apr & 2007 & 14-Mar & 4-Jun \\
\hline 1986 & 27-May & 1-Apr & 2008 & 5-Apr & 24-Apr \\
\hline 1987 & 4-May & 15-Mar & 2009 & 18-Apr & 25-Mar \\
\hline 1988 & 2-Jun & 2-Mar & 2010 & 28-Apr & 26-Apr \\
\hline 1989 & 12-May & 18-Mar & 2011 & 20-May & 27-Apr \\
\hline
\end{tabular}

rainfall onset mostly occurred in March in CP1 whereas in CP2 the onset of the rains was mainly in April.

Figure 12 shows the onset of rainfall in both Saltpond and Wenchi during 
CP1. Saltpond exhibited later onsets over this period and again showed an increasing trend. Meanwhile the onset dates in Wenchi were generally early as compared to that of Saltpond, with the exception of some years (1964, 1965, 1975 and 1977). The late onset of saltpond might be attributed to either human influence as a result of change in measuring instruments or data collection errors, or the location of Saltpond, which is just by the Sea, which went on to influence the local climate. Again, the early onset in Wenchi can also be attributed to the vegetation in the area, which has an influence on the local climate of the area.

Similarly, the onset of rainfall in both Saltpond and Wenchi in CP2 (Figure 13) revealed that again, rainfall onset was late in Saltpond as compared to Wenchi with the exception of 1996 and 2007. There was however, a decreasing trend in Saltpond, this thereby instigating that the onset for Saltpond in CP2 has shown some signs of coming early in later years.

\section{Conclusions}

This study used rainfall data from Saltpond and Wenchi representing the Coastal Savannah and Transition Savannah agro-ecological Zones of Ghana. In the study, two climatological periods CP1 (1968-1989) and CP2 (1990-2011) were considered for the changes in the trend of rainfall. Annual rainfall amounts, the onset of rainfall and extreme daily characteristics were compared for the two periods.

We report in this paper that the average rainfall amount has decreased over both agro-ecological zones but there was an increasing trend in rainfall pattern at present than in the past. Both study areas recorded larger rainfall amounts in $\mathrm{CP} 1$ relative to $\mathrm{CP} 2$. Both ecological zones depicted similar trend of CDDs and CWDs for the periods considered. A significant decrease in CDD was observed in CP1 and a non-significant increase in CDD was observed in CP2 over Saltpond and Wenchi. A decreasing CWD, which was not significant over both periods was observed for both study areas but the decreasing trend depicts the possibility of droughts in the present years which will be detrimental to farming practices in this area.

The results also showed that the onset of rains, which should normally start in March in Saltpond, [14] was most often late whereas that of Wenchi was mostly early (Table 1). The onset of rains in Saltpond was found to mostly occur in May for CP1 but occasionally swings between April and May in CP2. The onset of rains in Wenchi mostly occurred in March in CP1 whereas it was mainly April for CP2. This reveals that there have been shifts in the rainfall peaks across $\mathrm{CP} 1$ and CP2 but notably there has been a significant shift in that of Wenchi. These show a delaying trend in the dates of rainfall onset [17] with confirmation from farmers in the study areas.

Indeed there have been notable changes in rainfall pattern in both the Transition and Coastal Savannah agro-ecological Zones with regard to developments after the 2000s. It is therefore imperative for farmers to be encouraged to under- 
take better field management practices in other to improve their yields since changes in rainfall pattern are known to overall have negative impact on yields. Effects such as the shortening of farming seasons and irregular planting dates will lead to food insecurity which in turn affects the country's economy which relies heavily on these agro-ecological zones as its "bread-basket". In going forward, other farming practices such as irrigation should be introduced to help the farmers in these agro-ecological zones beat the challenges of the changing climate. We also recommend the establishment of enough early warning systems so as to help farmers in these areas with first-hand information to enable them withstand the variations in the climate of their agro-ecological zone. It should be noted that these findings have consequences on rain-fed agricultural practices as well as the socio-economic growth and the food security of Ghana.

\section{Acknowledgements}

This research was completed at the Department of Physics, University of Cape Coast, Ghana under the PEER Science Project with the kind support of the USAID.

\section{References}

[1] World Bank (2009) World Development Report. Washington DC.

[2] United States Department of Agriculture (USDA) (2010) Food Security Assessment, 2010-20. Report GFA-21, Economic Research Service, Washington DC.

[3] Stocker, T.F., Qin, D., Plattner, G.-K., Tignor, M., Allen, S.K., Boschung, J., Nauel, A., Xia, Y., Bex, V. and Midgley, P.M. (2013) Technical Summary. Climate Change 2013: The Physical Science Basis. Contribution of Working Group I to the Fifth Assessment Report of the IPCC.

[4] Nicholson, S.E., Some, B. and Kone, B. (2000) An Analysis of Recent Rainfall Conditions in West Africa, Including the Rainy Seasons of the $1997 \mathrm{El}$ Nino and the 1998 La Nina Years. Journal of Climate, 13, 2628-2640. https://doi.org/10.1175/1520-0442(2000)013<2628:AAORRC >2.0.CO;2

[5] Chappell, A. and Agnew, C.T. (2004) Modelling Climate Change in West African Sahel Rainfall (1931-90) as an Artifact of Changing Station Locations. International Journal of Climatology, 24, 547-554. https://doi.org/10.1002/joc.1021

[6] Malhi, Y. and Wright, J. (2004) Spatial Patterns and Recent Trends in the Climate of Tropical Rainforest Regions. Philosophical Transactions of the Royal Society B, 359, 311-329. https://doi.org/10.1098/rstb.2003.1433

[7] Lacombe, G., McCartney, M. and Forkuor, G. (2012) Drying Climate in Ghana over the Period 1960-2005: Evidence from the Resampling-Based Mann-Kendall Test at Local and Regional Levels. Hydrological Sciences Journal, 57, 1594-1609. https://doi.org/10.1080/02626667.2012.728291

[8] Owusu, K. and Waylen, P. (2012) The Changing Rainy Season Climatology of mid-Ghana, 2012. Theoretical and Applied Climatology, 112, 419-430.

[9] Shongwe, M., Van Oldenborgh, G., Van Den Hurk, B., De Boer, B., Coelho, C. and Van Aalst, M. (2009) Projected Changes in Extreme Precipitation in Africa under Global Warming. Part 1: Southern Africa. Journal of Climate, 22, 3819-3837. https://doi.org/10.1175/2009JCLI2317.1 
[10] Tadross, M., Hewitson, B. and Usman, M. (2005) The Interannual Variability of the Onset of the Maize Growing Season over South Africa and Zimbabwe. Journal of Climate, 18, 3356-3372. https://doi.org/10.1175/JCLI3423.1

[11] Hewitson, B.C. and Crane, R.G. (2006) Consensus between GCM Climate Change Projections with Empirical Downscaling: Precipitation Downscaling over South Africa. International Journal of Climatology, 26, 1315-1337. https://doi.org/10.1002/joc.1314

[12] Sylla, M.B., Gaye, A.T., Jenkins, G.S., Pal, J.S. and Giorgi, F. (2010) Consistency of Projected Drought over the Sahel with Changes in the Monsoon Circulation and Extremes in a Regional Climate Model Projections. Journal of Geophysical Research, 115, D16108. https://doi.org/10.1029/2009JD012983

[13] Stumpf, E. (1998) Post-Harvest Loss Due to Pests in Dried Cassava Chips and Comparative Methods for Its Assessment-A Case Study on Small-Scale Farm Households in Ghana. PhD Thesis, Faculty of Agriculture and Horticulture, Humboldt-University Berlin.

[14] Nkrumah, F., Klutse, N.A.B., Adukpo, D.C., Owusu, K., Quagraine, K.A., Owusu, A. and Gutowsky, W. (2014) Rainfall Variability over Ghana: Model versus Rain Gauge Observation. International Journal of Geosciences, 4, 673-683.

https://doi.org/10.4236/ijg.2014.57060

[15] Adiku, S.G.K., Mawunya, F.D., Jones, J.W. and Yangyuoru, M. (2007) Can ENSO Help in Agricultural Decision-Making in Ghana? Climate Prediction and Agriculture Advances and Challenges. Springer-Verlag, Berlin Heidleberg, 205-212.

[16] Adiku, S.G.K., Atika, E., Jagtap, S.S., Nkansah, A., Atidoh, L., Jones, J.W., Duadze, S. and Naab, J.B. (2007) Climate Variability and Farmers' Response in the Groundnut Producing Areas of the Akatsi District of Ghana. Conference Paper, African Soil Science Society, Accra.

[17] Klutse, N.A.B., Owusu, K., Adukpo, D.C., Nkrumah, F., Quagraine, K., Owusu, A. and Gutowski, W.J. (2013) Farmer's Observation on Climate Change Impacts on Maize (Zea mays) Production in a Selected Agro-Ecological Zone in Ghana. Research Journal of Agriculture and Environmental Management, 2, 394-402.

\section{Submit or recommend next manuscript to SCIRP and we will provide best service for you:}

Accepting pre-submission inquiries through Email, Facebook, LinkedIn, Twitter, etc. A wide selection of journals (inclusive of 9 subjects, more than 200 journals)

Providing 24-hour high-quality service

User-friendly online submission system

Fair and swift peer-review system

Efficient typesetting and proofreading procedure

Display of the result of downloads and visits, as well as the number of cited articles

Maximum dissemination of your research work

Submit your manuscript at: http://papersubmission.scirp.org/

Or contact ijg@scirp.org 